Technical Report 1077

\title{
Predicting Performance Ratings Using Motivational Antecedents
}

\author{
Michelle M. Zazanis and Martha S. Lappin \\ U.S. Army Research Institute
}

Organization and Personnel Resources Research Unit

Paul A. Gade, Chief U.S. Army Research Institute for the Behavioral and Social Sciences
5001 Elsenhower Avenue, Alexandria, Virginla 22333-5600

$$
\text { January } 1998
$$

Approved for public release; distribution is unlimited. 